\title{
O NOWY KSZTAŁT WSPÓŁPRACY BIBLIOTEKI UNIWERSYTECKIEJ W WARSZAWIE $Z$ BIBLIOTEKAMI B. ZSRR W ZAKRESIE KSIĘGOZBIORÓW HISTORYCZNYCH
}

Zbiory biblioteczne Uniwersytetu Warszawskiego gromadzone na potrzeby powstałej w 1816 r. uczelni, a także jako substytut ksiażnicy narodowej tj. Biblioteki Załuskich, wywiezionej do Rosji po lll rozbiorze Polski, w znacznej cześci podzieliły los swojej poprzedniczki. Wywożono je bowiem dwukrotnie w tym samym kierunku. Pienwszy raz, po upadku Powstania Listopadowego w $1831 \mathrm{r}$. opieczętowano, a następnie wywieziono do Petersburga ok. 62\% stanu posiadania Biblioteki Publicznej przy Uniwersytecie Warszawskim. Wśród utraconego dziedzictwa narodowego było ok. 100 tysięcy książek, w tym kilka tysięcy inkunabułów, a ponadto rękopisy, mapy, medale, numizmaty, zbiory graficzne, bezcenne czasopisma z początku XIX wieku'. Razem ze spuścizną uniwersytecką do Rosji zabrano ok. 66\% zasobów Warszawskiego Towarzystwa Przyjaciół Nauk tj. ok. 30 tysięcy książek i kilkaset rękopisów. Ponieważ jednak pozostałe w Warszawie resztki kolekcji TPN przejęta książnica uniwersytecka w 1834 r., nic dziwnego, że obecnie funkcjonująca Biblioteka Uniwersytecka jest zainteresowana także losami tego księgozbioru ${ }^{2}$.

Po raz drugi ewakuacja części zbiorów UW miała miejsce w 1915 r. wraz z ustępowaniem Rosjan z Warszawy. Wywieziono wówczas do Moskwy, a stamtąd do Rostowa nad Donem, pozostałe w Uniwersytecie rękopisy oraz najcenniejsze druki XVI wieku zgromadzone w tzw. 28 sali $^{3}$ wraz z archiwum bibliotecznym.

Nie jest więc tak, jak to się czyta nieraz w ostatnich latach w rozmaitych publicystycznych relacjach, iż ze zbiorów warszawskich na terenie b. ZSRR pozostala tylko część bezcennej Książnicy Załuskich oraz zamkowa kolekcja Stanisława Augusta Poniatowskiego.

Niewiele wywiezionych zasobów odzyskała jednak Biblioteka Uniwersytecka jeszcze w okresie zaborów. Były to wszakże drobne fragmenty kolekcji, nie zawsze bezpośrednio związane z Uniwersytetem Warszawskim, jak np. kilka tysięcy druków z Biblioteki Załuskich, ofiarowanych Warszawie jako dublety w stosunku do zasobów rosyjskich. O całość historyczną kolekcji oczywiście wówczas nie dbano, stosując w wyborze materiałów jedynie kryterium bibliograficzne.

Teoretycznie znacznie poważniejsze możliwości rewindykacyjne stworzył dopiero Traktat Ryski z 1920 r. Sprawa zbiorów uniwersyteckich stała się w nim częścią ogromnego problemu odzyskania polskich dóbr kultury, wywożonych przemocą do Rosji w latach $1772-1918^{4}$. Głównym ekspertem bibliotecznym w tym 
zakresie oraz tropicielem zasobów stołecznej uczelni do r. 1923 był dr Stefan Rygiel, późniejszy dyrektor BUW, pełnomocnik delegacji polskiej w komisjach mieszanych: reewakuacyjnej oraz specjalnej. Zbiorami uniwersyteckimi zajmowad się także prof. Zygmunt Batowski działający na rzecz odzyskania Gabinetu Rycin. Ich pracy, a także całego zespołu bibliotecznego, poświęcono wiele publikacji, mimo to nie wszystkie aspekty zagadnienia są dostatecznie wyświetlone ${ }^{5}$. Nie wchodząc $w$ tym miejscu w szczegóły tego frapującego przedsięwzięcia, trzeba wszakże powiedzieć, że niezwykle trudna i żmudna praca komisji nie przyniosła w pełni pierwotnie oczekiwanych rezultatów, zwłaszcza w zakresie odzyskania zagarniętych książek, szczególnie starych druków, a to z kilku co najmniej powodów. Wśród nich wymienić trzeba przede wszystkim problem dostępu do źródeł dokumentujących wywiezione zasoby. W odniesieniu do kolekcji uniwersyteckich był on nader mizerny, bowiem wg opinii M. Łodyńskiego, opartej na świadectwie ówczesnego dyrektora Biblioteki przy Królewskim Warszawskim Uniwersytetcie S.B.Lindego, wraz ze zbiorami wywieziono po Powstaniu Listopadowym także „... katalogi, a nadto wszystkie księgi zapisów porządkowych, jak inwentarze, raptularze, księgi obecności personelu, księgi czytelników, księgi darów i ofiarodowaców itd." Zasadniczo lepiej przedstawiała się możliwość odzyskania nierozproszonych zbiorów graficznych, był bowiem do dyspozycji inwentarz Mikołaja Utkina, który stał się podstawą rewindykacji zasobu Gabinetu Rycin UW ${ }^{7}$. Udało się też rewindykować znaczną część zbiorów rękopiśmiennych, wśród których było 1000, z wywiezionych 1837 rękopisów należących do Biblioteki Uniwersyteckiej oraz kilkaset z Towarzystwa Przyjaciół Nauk (wywieziono 346). Odzyskanie tak ważnego materiału historycznego, jaki zawsze stanowią rękopisy, było możliwe, wg słów Piotra Wojkowa, przewodniczącego delegacji radzieckiej w komisji mieszanej, m.in. z dwóch powodów: „... po pierwsze dlatego że, mówiąc szczerze rękopisy w bibliotece (Publicznej w Leningradzie) przechowywano, bynajmniej jednak nie włączano ich po należytym opracowaniu do działu rękopisów, po drugie - ponieważ najlepsi uczeni (rosyjscy) naszych czasów ku swemu zawstydzeniu nie potrafili określić wartości tych rękopisów w ogóle" 8 .

Inną poważną przeszkodą akcji rewindykacyjnej było to, iż komisja mieszana zmuszona była uznać zbiory byłej Cesarskiej Biblioteki Publicznej w Petersburgu za światowe dziedzictwo piśmiennictwa, a co za tym idzie musiała tę książnicę możliwie oszczędzać, choć powstała ona właśnie na kanwie zrabowanych zbiorów polskich, w tym uniwersyteckich. Poza rękopisami usiłowano przeto zabiegać o najrzadsze drukowane polonica, o pojedyńcze, szczególnie cenne egzemplarze książek mających związek z kulturą polską (tu odbyła się długa dysputa prawnicza i historyczna co oznacza pojęcie „ścisły związek”), o pomniki drukarstwa polskiego i światowego należące ongiś do polskich zbiorów, a także o niektóre cale zespoły petersburskiej Biblioteki Publicznej tzw. „fondy” jak np. „Polska”, „Dublety” itp. Trzeba wszakże pamiętać, że Rosjanie przykładali się maksymalnie, aby utrudniać odbiór pozycji nawet uzgodnionych i spłacać „dlugi” wybranym przez nich ekwiwalentem z druków uznanych za mniej ważne. W przeciwieństwie do rękopisów właściwie do dzisiaj nie wiadomo ostatecznie ile książek wróciło do Polski. „Znacznie trudniej poszła sprawa z odbiorem druków, tak inkunabułów, jak i druków 
nowszych. Ekspertyza sowiecka broniła niezwykle zaciekle tej pozycji, a wszelkit próby strony polskiej złamania tego uporu nie dawały rezultatu" - stwierdza E. Kuntze - przewodniczący delegacji polskiej od $1923 r^{9}$. Ostatecznie wg jego oceny tylko z Biblioteki Publicznej w Leningradzie otrzymano 1987 inkunabułów i ok. 66 tysięcy pozycji w 70631 woluminach druków wywiezionych w XIX wieku. Doliczając ponadto książki z innych bibliotek, było ich w sumie jakoby 88090 tomów. Nie wiadomo przy tym, jaki procent w tym stanowiły stare druki, ani też oczywiście, ile $z$ nich należało do dawnych kolekcji uniwersyteckich.

Natomiast z reewakuacji związanej z I wojną światową Uniwersytet odzyskał cały zasób druków wspomnianej 28 sali oraz rękopisy, bez jednej, prawdopodobnie zbombardowanej, skrzyni. Ponadto Instytut Nauk Biologicznych Warszawskiego Towarzystwa Naukowego odzyskał bibliotekę znanego fizjologa i chemika Władysława Nenckiego, a także 279 skrzyń książek należących do profesorów przebywających w Rosji m.in. Władysława Kotwicza, Leona Petrażyckiego, Wiktora Porzezińskiego, Stanisława Ptaszyckiego i innych.

Obiekty rewindykowane w latach 1923-1935 z Rosji do Polski składowano początkowo w Bibliotece Uniwersytetu Warszawskiego. Dr Rygiel przebudował nawet wnętrze gmachu, aby poprawić jego funkcjonalność oraz pomieścić odzyskane skarby. Wkrótce jednak energiczna akcja Stefana Dembego, naczelnika Wydziału Bibliotek przy Ministerstwie Wyznań i Oświecenia Publicznego, dażącego uparcie do materialnego zrealizowaniá idei narodowej książnicy w niepodległym państwie, doprowadziła do decyzji przekazania całości rewindykowanych zasobów do tworzącej się od 1927 r. Biblioteki Narodowej, a więc nawet tych, które należały do Biblioteki Publicznej przy Uniwersytecie Warszawskim oraz do książnicy Towarzystwa Przyjaciół Nauk, przechowywanej, jak wspomniałam, od 1834 r. w Uniwersytecie. Wydano wówczas ponad 9 tysięcy rękopisów oraz 47 tysięcy druków z XV-XVIII wieku, w tym 1829 vol. inkunabułów ${ }^{10}$. Ile z nich należało do dawnego zasobu uniwersyteckiego - nie wiadomo.

Decyzja ta zbulwersowała część środowiska uczelnianego, bowiem o ile nie roszczono pretensji do sukcesji po Bibliotece Zaruskich i innych skasowanych instytucjach, o tyle przekazanie odzyskanego z takim trudem dziedzictwa uniwersyteckiego, a więc zbiorów istniejącej wówczas legalnie instytucji, sprawiło zawód braci bibliotekarskiej i części kadry nauczającej. Decyzję tę trzeba tłumaczyć z jednej strony, entuzjazmem społeczeństwa dla organizującej się kolejnej centralnej instytucji niepodległego państwa, a z drugiej strony małym zainteresowaniem władz uniwersytetckich tymi sprawami, wobec trudnej sytuacji organizacyjnej i lokalowej w bibliotece oraz na uczelni. W r. 1936 ostatecznie odwołano ze stanowiska dyrektora biblioteki Stefana Rygla, zasłużonego uczestnika akcji rewidykacyjnej. Władze uczelni zajęte były przede wszystkim przekształceniem dotychczasowego prowincjonalnego rosyjskiego uniwersytetu w nowoczesna placówke dydaktyczna i naukową. Zamysł ten wymagał także unowocześnienia warsztatu bibliotecznego, co w praktyce oznaczało zwrócenie uwagi przede wszystkim na zbiory nowsze i nowe, a nie na dziedzictwo historyczne. Rozrastająca się żywiołowo biblioteka już wówczas potrzebowala przestrzeni magazynowej, a niewielka ilość pracowników, choć ofiarnych, skłaniała raczej do pozbycia się niektórych partii zbiorów, niż do 
energicznej akcji zmierzającej do przyłączenia rewindykowanych zasobów dawnych. W ten sposób doszło też do bolesnej decyzji przekazania w r. 1935 i 1936 na rzecz Biblioteki Narodowej naszych zbiorów muzycznych i kartograficznych.

Dodać trzeba melancholijnie, że większość rewindykowanych i przekazanych do Biblioteki Narodowej zbiorów odzyskanych z Rosji, spłonęła podczas Powstania Warszawskiego w 1944 r., zanim ktokolwiek zdążył je poważnie opisać. Odnosi się to przede wszystkim do druków. Tak oto BUW stracila bezpowrotnie poważną część swoich zasobów historycznych. Na szczęście ocalała ta ich część, która pozostała na miejscu w Warszawie oraz - choć brzmi to paradoksalnie - ta część, która pozostała w bibliotekach Leningradu i Moskwy ${ }^{11}$.

Wszakże pomimo zapisu punktu B Rezolucji w sprawie wydania Rządowi Polskiemu rękopisów i ksiagg... z 31.X.1922 r., mówiącego wyraźnie, iż „obie układające się strony...będą mogły korzystać obopólnie z materiałów naukowych rękopiśmiennych i drukowanych w miejscach ich przechowywania" - korzystanie bibliotekarzy polskich z zasobów radzieckich było w praktyce niemożliwe. Nie mieli oni bezpośredniego dostępu do zbiorów, ani też do materialów archiwalnych dokumentujących te zbiory. Czasami nawet Polakom, jak się zdarzyło w 1978 r. w Wilnie piszącej te słowa, nie można było korzystać z publicznego katalogu opracowanych zasobów. Na pisemne kwerendy z Polski nie odpowiadano w ogóle lub odpowiadano wymijająco. Drukowane katalogi opracowane m.in. na kanwie dawnych zbiorów polskich, nie zawierały przeważnie danych na temat ich proweniencji. W ten sposób BUW odcięto fizycznie nie tylko od poważnej części swoich kolekcji historycznych, ale uniemożliwiono podjęcie retelnych prac dokumentacyjnych i naukowych.

Problem naszych zbiorów wywiezionych do Rosji stanowi fragment, aczkolwiek istotny, szerokiego zagadnienia historycznych księgozbiorów polskich i w Polsce przechowywanych, a rozproszonych na terenie naszego kraju i poza nim na przestrzeni kilku wieków, poczynając od wojen szwedzkich. Kierunek rozproszenia nie sięga więc tylko wschodu, choć w przypadku Biblioteki Uniwersyteckiej jest najważniejszy ${ }^{12}$.

Dlatego też stare zasoby bibliotek leningradzkich i moskiewskich, a także po trosze $\mathrm{i}$ innych miast, powinny interesować szczególnie pracowników Oddziału Starych Druków BUW. Jest i inny powód tego zainteresowania. Otóż na skutek uwarunkowań historycznych, o których była już częściowo mowa, Biblioteka Uniwersytecka w Warszawie jest najzasobniejszą obecnie książnicą polską w zbiory zaliczane do kategorii „rossica”. Stało się to za przyczyną kilkakrotnych „darów Najjaśniejszego Pana", ofiarowanych zwłaszcza w latach 1840-1842, w postaci druków zbędnych z bibliotek: Cesarskiej, Sztabu Generalnego, Ermitażu, Akademii Nauk, a także dubletów przysyłanych z Petersburga do Warszawy w okresie liberalnej polityki oświatowej A. Wielopolskiego w latach 1862-1863. Przyczyniła się do tej sytuacji także rusyfikacyjna polityka gromadzenia, prowadzona $w$ agendzie rosyjskiej uczelni, jaką była nasza biblioteka w latach 1871-1915. Wówczas to znalazlo w niej schronienie wiele ksiegozbiorów Rosjan - profesorów tej uczelni oraz urzędników rosyjskich, jak choćby znakomita, bibliofilska kolekcja A.A. Tołoczanowa, długoletniego urzędnika rosyjskiego w polskich miastach gubernialnych, 
a ostatecznie prezesa Towarzystwa Kredytowego Ziemskiego w Warszawie, przekazana do Uniwersytetu w r. 1897 na mocy testamentu zmarłego właściciela ${ }^{13}$. Część rossików, zwłaszcza wydawnictw źródłowych i czasopism, przybyło w następstwie akcji rewindykacyjnej po Traktacie Ryskim, jako tzw. ekwiwalenty za zbiory pozostawione w Rosji. Tę specyfikę zbiorów BUW niewątpliwie dostrzegamy udostępniając poprzez drukowane katalogi i opracowania bogaty zasób piśmiennictwa rosyjiskiego. Dażenie to znalazło wyraz np. w zapoczątkowanym Katalogu czasopism rosyjskich Biblioteki Uniwersyteckiej $w$ Warszawie, obejmującym periodyki drukowane w języku rosyjskim na terenie byłego imperium rosyjskiego i poza jego granicami od pierwszej polowy XVIII wieku po rok 1916. Tom I tego wydawnictwa rejestrujący tytuły w porządku alfabetycznym od A do J wydano w $1987 \mathrm{r}$. pod redakcją Edwarda Stańczaka. W druku natomiast znajduje się obszerne opracowanie Oleny Błażejewicz omawiające dzieje naszej biblioteki w latach 1871-1915, czyli w tym okresie, gdy nosila ona nazwę Biblioteki Imperatorskogo Warszawskogo Uniwersiteta.

Jeśli idzie o zbiory starsze - należy wskazać na największą w Polsce kolekcję druków rosyjskich XVIII wieku tłoczonych grażdanką. Tworzy ją zespół liczący ok. 1500 pozycji bibliograficznych, notowanych przeważnie w Sodnom kataloge russkoj knigi XVIII wieka 1725-1800. Nie są tu zatem istotne rzadkości bibliograficzne, choć mamy nieraz jedyne na terenie Polski egzemplarze rozmaitych dzieł ale przede wszystkim pierwotne zasoby, z których one pochodza. Nierzadko są to znane historyczne kolekcje rosyjskie, będące przedmiotem badań historyków książki.

Niewiele natomiast mamy druków cyrylickich, ale i w tej grupie zbiorów znajdują się rzadkości bibliograficzne, jak np. wydania raskolnicze z Grodna, światowy unikat jednego z druków unickiej drukarni supraskiej, czy wreszcie słynna Biblia Ostrogska Fiodorowa z 1580 r., jeden z trzech zachowanych w świecie egzemplarzy zawierających tzw. karty wileńskie. W zakresie typografii cyrylickiej bez watpienia lepszym partnerem dla bibliotek naszych wschodnich sąsiadów jest warszawska Biblioteka Narodowa z wydzielonym znacznym zespołem druków cyrylickich, dysponujące ponadto centralnym katalogiem tych zbiorów w Polsce. Ma ona zresztą współpracować ze stroną rosyjską w zakresie sporządzenia światowego katalogu drukarstwa cyrylickiego.

Największą wszakże niespodziankę dla badacza kryje piśmiennictwo europejskie, przechowywane niegdyś w kolekcjach rosyjskich, a obecnie znajdujące się w zbiorach Biblioteki Uniwersyteckiej. Nie są to wprawdzie wielkości oszałamiające, choć np. tylko w grupie druków z XVl wieku odnajdujemy ok. 150 pozycji z petersburskiego księgozbioru Sztabu Generalnego, z biblioteki Akademii Nauk ok. 30 pozycji oraz kilka ze zbiorów w Ermitażu. Powyższe proweniencje występują liczniej w piśmiennictwie XVII i XVIII wieku, choć nie w pełni są jeszcze zarejestrowane. Sądzić należy, że dla rosyjskiego księgoznawcy ma znaczenie każdy volumen, który pochodzi ze znanej historycznej kolekcji carstwa, jak choćby Johanna Petera Suchtelena (1751-1836) generała w rosyjskiej służbie, której dotychczas ujawniony u nas fragment (ok. $50 \mathrm{dzief)}$ pozwala snuć interesujące wnioski odnośnie jego zainteresowań. Uwagę zwróci też zapewne dzieło z XVI wieku z rękopiśmienną notatką na egzemplarzu Serge et Alexandre Princes de 
Gallyczin ${ }^{14}$, czy wreszcie tom z biblioteki Iwana Szuwałowa (1727-1797), rosyjskiego męża stanu spokrewnionego z Golicynami, którego książka dotarła do Polski jeszcze w epoce przedrozbiorowej, czyli wówczas gdy w państwie naszym znajdującym się zasadniczo w kręgu kultury zachodniej, gromadzono głównie księgi napływające $z$ południa i zachodu Europy ${ }^{15}$. Niewiele zatem mamy, wyjąwszy drukarstwo ruskie, potwierdzonych kontaktów książkowych polsko-rosyjskich przed rokiem 1772.

Odtwarzanie zawartości i dziejów wielokrotnie przemieszczanych kolekcji, stanowi dzisiaj trudny problem badawczy, zarówno dla naszych wschodnich kolegów jak i dla bibliotekarzy polskich. Brak współpracy obu stron w zakresie badań proweniencyjnych prowadzi często do ewidentnych błędów, by wskazać tylko na jeden przykład z niewielkiego katalogu inkunabułów, wydanego na terenie ZSRR w 1981 r. Otóż na pewnym egzemplarzu ujawniono istnienie suchej pieczęci "AZEC”, którą w indeksie właścicieli objaśniono następująco: „Azec?poss(essor)?”, gdy tymczasem są to dobrze znane inicjały współtwórcy pienwszej polskiej książnicy narodowej, znaczące: $A$ (ndreas) Z(ałuski) $E$ (piscopus) $C$ (racoviensis). Z drugiej znów strony w kartotece proweniencyjnej Biblioteki Uniwersyteckiej w Warszawie jeszcze niedawno tj. przed wydaniem w roku 1985 pracy o historycznych znakach własnościowych książek przechowywanych w zbiorach Biblioteki Uniwersytetu Moskiewskiego ${ }^{16}$ mieliśmy takie to hasło: „Herb obcy z dewizą Fuimus". Chodzi tu oczywiście o bibliotekę uczonego i kolekcjonera Jakuba Briusa [Bruce] (16701735), współpracownika cara Piotra I, którego znakomity księgozbiór znalazł się w petersburskiej Akademii Nauk, a niewielkie jego odpryski są obecnie i w Polsce.

Wskazane powyżej problemy i przytoczone przykłady dowodzą, że powinniśmy wykazywać wzajemne zainteresowanie naszymi zbiorami bibliotecznymi. Nie chodzi tu wszakże - co trzeba wyraźnie powiedzieć - o kontynuowanie powojennej polityki informacyjnej, a właściwie antyinformacyjnej, o historycznych zasobach bibliotek w Polsce i w Zwiazku Radzieckim, wysoce nagannej i petnej niedomówień lub wręcz falszerstw. Nie chodzi tu także o wznowienie dążeń rewindykacyjnych. Upływające lata oraz wkład bibliotekarzy polskich, niemieckich, litewskich, białoruskich, ukraińskich i rosyjskich w żmudną pracę zabezpieczenia i uporządkowania księgozbiorów zniszczonych przez wojny i odwet polityków, uświadamiają nam dostatecznie, że jakiekolwiek dalsze przemieszczanie książek doprowadzi do kolejnego, gigantycznego bałaganu w zasobach tej czesści Europy, niezależnie od racji historycznych. Trzeba bowiem mieć wyobraźnię, by uzmystowić sobie, co oznacza wyrwanie z całokształtu wielkiego księgozbioru kilkudziesięciu tysięcy starych ksiażek $i$ ich nowe opracowanie. Jest to zadanie na dziesięciolecia ${ }^{17}$. Odmienne postępowanie może mieć jedynie rację bytu, gdy ma się do czynienia z luźnymi zespołami książek, nie związanymi z całością biblioteki, dotychczas nie opracowanymi i zbytecznie zajmującymi miejsce w magazynie, bądź też zagrożonymi zniszczeniem. Te mogą być ewentualnie, w zależności od ich sytuacji prawnej, przedmiotem zwrotu, wymiany, sprzedaży itp.

Przejawiające się w latach siedemdziesiątych, a zwłaszcza osiemdziesiątych dążenie do jednoczenia kultury europejskiej, pokazało środowisku bibliotekarskiemu państw nękanych wojnami i represjami polity cznymi inną drogę działania. Mowa 
tu o konieczności rozbudowania prawdziwej bazy informacyjnej o przejętych zasobach oraz otwarcie jej dla zainteresowanych badaczy, w pierwszym rę̧dzie ich dawnych właścicieli. Pożądana jest zatem ściślejsza współpraca naszej biblioteki z instytucjami Leningradu i Moskwy, szczególnie w aspekcie opracowania katalogowego zbiorów, ujawniania archiwaliów bibliotecznych oraz mozolnej pracy odczytywania i interpretowania dawnych znaków własnościowych. Sądzę, że Biblioteka Uniwersytecka $w$ Warszawie, od lat prowadząca badania proweniencyjne swoich zbiorów, może być pożądanym partnerem bibliotekarzy zatrudnionych w rosyjskich oddziałach ksiażki rzadkiej i cennej.

Nie idzie tu przy tym o okazjonalne, dwu-trzytygodniowe wymiany wizyt. Problem jest tak ogromny, a ilość pracy tak niezmierzona, szczególnie po stronie polskiej, że powinien być nawiązany stały, roboczy kontakt Biblioteki Uniwersyteckiej w Warszawie przynajmniej z leningradzką Biblioteką Publiczną im.SałtykowaSzczedrina oraz Akademii Nauk. Należałoby rozważyć kwestię, czy Uniwersytet Warszawski lub Ministerstwo Edukacji Narodowej nie może przeznaczyć pewnych środków finansowych na odpowiedni program badawczy, który mialby na celu przeanalizowanie zagadnienia dziedzictwa kulturowego stołecznej uczelni, rozproszonego $w$ archiwach i bibliotekach naszych wschodnich sąsiadów. A może, korzystając ze spodziewanego ożywienia we wzajemnych stosunkach kulturalnych, należałoby wrócić do przedstawionej przez Józefa Siemieńskiego w 1925 r. na IV Zjeździe Powszechnym Historyków Polskich w Poznaniu koncepcji zorganizowania na terytorium ZSRR stałej polskiej stacji naukowej, na wzór działających w Rzymie i Paryżu? Wniosek ten powtórzył dziesięć lat później w Wilnie na V! Zjeździe Historyków Stefan Ehrenkreutz optując za siedzibą stacji w Moskwie ${ }^{18}$. II wojna światowa i stosunki powojenne uniemożliwiły zrealizowanie tej niewątpliwie słusznej idei.

Tak czy inaczej - mimo trudnej sytuacji ekonomicznej państwa oraz ogólnie złego stanu personalnego bibliotek polskich, należy wykorzystać polityczną szansę uzdrowienia kontaktów kulturalnych i naukowych ze wschodnimi sąsiadami, szansę jaką niosą współczesne nam dni. Tylko bowiem odpowiedni ośrodek informacyjnobadawczy ze stałym, wzajemnym dostępem do interesujących obu partnerów kolekcji, spowoduje rzetelne, naukowe funkcjonowanie utraconych księgozbiorów lub ich fragmentów. Zamknięte $w$ magazynach byłego imperium sowieckiego skarby naszej kultury narodowej, zebrane niegdyś trudem pokoleń Polaków w byłej Bibliotece Publicznej przy Uniwersytecie Warszawskim, muszą stać się dostępne dla cywilizowanej Europy.

\section{Przypisy}

${ }^{1}$ Szczegółowe dane na temat ilości wywiezionych zbiorów różnią się nieco między sobą. Tak np. S.B. Linde $w$ swych raportach podaje, iż "z calej zaś Biblioteki Publicznej Warszawskiej pr zewieziono przeszło voluminów 90 000" nie licząc zbiorów przynależnych do Gabinetu Rycin, zob. M. Łodyński, Materiały do dziejów państwowej polityki bibliotecznej w Księstwie Warszawskim i Królestwie Polskim (1807-1831), Wroclaw, 1958, s. 204. P. Wojkow mówi o wywiezieniu z Biblioteki Publicznej przy Uniwersytecie Warszawskim 100941 książeki map, w tym rękopisy (1837), wszystkie inkunabuly (6118), a ponadto zbiory graficzne: rysunki, ryciny, dzieła ilustrowane, zob. J. Kumaniecki, Tajny raport Wojkowa, czyli radziecka taktyka zwrotu polskiego mienia gospodarczego i kulturalnego po pakoju ryskim, Warszawa, 1991, s. 177. S. Rygiel przygotowując teoretyczne podstawy rewindykacji potwierdza w 
zasadzie dane Wojkowa precyzując straty Biblioteki Uniwersyteckiej na 62\%, a TPN na 66\%. Odnosi się to wszakże tylko do zbiorów Cesarskiej Biblioteki Publicznej w Petersburgu, natomiast ile zbiorów polskich znajduje się w innych bibliotekach rosyjskich nie da się tego określić nawet w przybliżeniu, zob. Memorandum w sprawie zwrotu rękopisów i książek polskiego pochodzenia przechowywanych w Państwowej Bibliotece Publicznej w Petersburgu, w: Dokumenty dotyczące akcji Delegacji Polskich w Komisjach Mieszanych Reewakuacyjnej i Specjalnej w Moskwie, z. 8, 1923, 5. 27. Informacje H. Kozerskiej dotyczą 90505 druków, 1856 rękopisów, 984 map i atlasów oraz kolekcji medali, numizmatów i 102501 jednostek zbiorów graficznych Gabinełu Rycin, zob. Warszawska Biblioteka Uniwersytecka 1832-1871, Warszawa, 1967, s. VI.

${ }^{2}$ Badaniem tej kolekcji zajmuje się od kilkunastu lat U. Paszkiewicz, zob. jej publikacje: Narastanie ksieggozbioru Biblioteki Towarzystwa Przyjaciół Nauk w Warszawie (1802-1832), w: Z badań nad poiskimi księgozbiorami historycznymi, z. 3., Warszawa, 1977, s. 57-100 oraz Księgozbiór Stanisława Staszica w Bibliotece Uniwersyteckiejw Warszawie. Studium proweniencyjne, tamże, z. 9, Warszawa, 1986, s. 79-124.

${ }^{3}$ Zespół ten wyodrębnił z ogólnego zbioru w magazynie oraz osygnowal T. Wierzbowski w latach 1886-1889, przygotowując się do wydania katalogu Polonica XV et XVI ss. sive catalogus librorum res polonicas tranctantium vel a Polonis conscriptorum arte typographica impresorum, qui in Bibliotheca Universitatis Caesareae Varsoviensis asservantur..., zob. K. Niklewiczówna, Oddział Starych Druków Biblioteki Uniwersyteckiej w Warszawie 1949-1977, w: Z badań... z. 8, Warszawa, 1985, s. 6.

${ }^{4}$ Zob. wskazane powyżej memorandum S. Rygla oraz nowsze opracowania syntetyczne, jak np. rozdzial Udzial polskich uczonych wrewindykacji mienia kulturalnego, w: J. Róziewicz: Polsko-radzieckie stosunki naukowe w latach 1918-1939. Wrocław, 1979, s. 47-79, a także wstęp J. Kumanieckiego do publikacji: Tajny raport Wojkowa..., Warszawa, 1991.

${ }^{5}$ Zob. m.in. sprawozdania prasowe S. Rygla jaknp. Zwrot zabytków. Księgozbiór Biblioteki Publicznej Uniwersytetu Warszawskiego, w: „Rzeczpospolita”, 1921 nr 93, opracowanie Z. Batowskiego, Zbiór graficzny w Uniwersytecie Warszawskim, Warszawa, 1928, a przede wszystkim rozprawę E. Kuntzego, Zwrot zbiorów bibliotecznych z Rosji. Kraków, 1937. Autor gorzko wyznaje na s. 7 ; „Im dłużej przeciągahy się prace odbiorcze Delegacji Polskiej tym bardziej słablo zainteresowanie do nich w społeczeństwie poiskim i w polskich kolach naukowych, które pochlaniały własne prace i studia. Z drugiej strony zmniejszył się z upływem lat i sztab pracowników naukowych Delegacji; nieliczni, którzy pozostali, byli tak zajęci wytężającą pracą odbiorczą, że na opracowanie rezultatów odbiorów, a już wcale przebiegu calej akcji brakło im czasu i ochoty...".

${ }^{6}$ M. Łodyński, Materiały do dziejów... s. 307. Slowa Lindego brzmią następująco: „....spisy dawniejszych do Biblioteki Publicznej wcielonych dziel zabrane zostaly do Petersburga i że nawet karteczkowe przygotowania tak do oddziałowego, jako i ogólowego katalogu równegoż losu wraz z książkami doznaty..." s.203.

${ }^{7}$ Z. Batowski, Zbiór graficzny... 5. 8: „nie bez pewnych jednak braków".

${ }^{8}$ J. Kumaniecki, Tajny raport Wojkowa... s. 188.

${ }^{9}$ E. Kuntze, Zwrot zbiorów bibliotecznych... s. 28.

${ }^{10}$ Ilość starych druków określono na podstawie sprawozdania Biblioteki Narodowej o przejętych rewindykatach, zob. P. Buchwald-Pelcowa, Zakład Starych Druków i Ośrodek Opieki nad Dawna Książka, w: 50 lat Biblioteki Narodowej 1928-1978. Warszawa, 1984 s. 160.

${ }^{11}$ Zasadniczy zrąb zbiorów uniwersyteckich ulokowanow Cesarskiej Bibliotece Publicznej w Petersburgu (obecnie Państwowa Biblioteka Publiczna im. M.E. Saltykowa-Szczedrina). Nagromadzenie w jednym miejscu olbrzymiej ilości ksiąg doprowadziło do nieodpowiedniej polityki dubletowania zbiorów, a w jej rezultacie do rozbicia historycznych zespolów pośród prawie wszystkich większych instytucji naukowych ówczesnego imperium.

12 Tematyką rozproszenia polskich zbiorów historycznych i obcych w Polsce przechowywanych, zajęło się powstałe w 1989 r. Polskie Towarzystwo Bibliologiczne. Po ustaleniu wstępnych zalożeń z inicjatywy tegoż Towarzystwa utworzono, za zgodą Ministerstwa Kultury i Sztuki, w Bibliotece Narodowej specjalna pracownię, której zadaniem jest przygotowanie centralnego informatorium o zbiorach przemieszczonych.

${ }^{13}$ Zob. M. Brykalska, Księgozbiór Arkadego Tołoczanowa w Bibliotece Uniwersytetu Warszawskiego, „Roczniki Biblioteczne", 1959, z. 1/2. 
${ }^{14}$ na egzemplarzu dziela: I. Leunclavius, Historiae Musulmanae...libri XVIII. Francofurti, 1591.2 sygn. BUW Sd 602.594.

${ }^{15}$ M.A. Laugier, Essai sur l'architecture. Paris, $1753.8^{\circ}$, sygn. BUW 12.10.9.89.

${ }^{16}$ E.S. Kaszutina, N.G. Saprikina, Exlibris w sobranii Naucznoj Biblioteki Moskowskogo Gosudarstwennogo Uniwersiteta. Album-katalog. Moskwa, 1985, s. 55.

17 dla ilustracji problemu przypomnijmy, iż w Bibliotece Uniwersyteckiej we Wrocławiu nadal trwaja prace katalogowe nad księgozbiorami historycznymi, zgromadzonymi tam z terenów całego Śląska. Nadal też opracowuje się księgozbiory poniemieckie w Bibliotece Narodowej, nagromadzone po $1945 \mathrm{r}$.

18 J. Róziewicz: Polsko-radzieckie stosunki naukowe... s. 73. 